\title{
Author Index to Volume 39 - 2012
}

\begin{tabular}{|c|c|c|c|c|c|c|c|}
\hline Abdelmalik, P.A. & (MAY) & Beers, C.A. & (MAY) & Chang, H.T. & (NOV) & Demaerschalk, B.M. & $(\mathrm{NOV})$ \\
\hline Abood, C. & $(\mathrm{NOV})$ & Bell, E. & (MAR) & Chen, G-Z. & (SEPT) & De Matteis, S. & $(\mathrm{JAN})$ \\
\hline Abruzzo, T.A. & (JULY) & Belzil, V.V. & (MAR) & Chen, H. & (JULY) & Demchuk, A.M. & (JULY) \\
\hline Adamec, I. & (SEPT) & Ben-yan, L. & $(\mathrm{JAN})$ & Chen, J. & $(\mathrm{SEPT})$ & De Michele, G. & (JAN) \\
\hline & (NOV) & Bernard, G. & $(\mathrm{JAN})$ & Chen, R. & $(\mathrm{JAN})$ & Descoteaux, M. & $(\mathrm{NOV})$ \\
\hline Afshani, M. & (MAY) & & (MAR) & & (JULY) & Dhingra, V. & (SEPT) \\
\hline Ahmad, A. & (MAY) & Bernstein, M. & $(\mathrm{JAN})$ & Cheng, C. & (NOV) & Di Maio, L. & $(\mathrm{JAN})$ \\
\hline Ahuja, C. & (SEPT) & Bertoni, F. & $(\mathrm{NOV})$ & Cheng, G-P. & $(\mathrm{SEPT})$ & Diodati, D. & (MAR) \\
\hline Akagami, R. & (JULY) & Berzins, S. & (MAR) & Chertkow, H. & (NOV) & Dion, P.A. & $(\mathrm{JAN})$ \\
\hline Akman, C.I. & (SEPT) & Beschorner, R. & (JULY) & Chew, J.B. & (MAY) & Doja, A. & (MAY) \\
\hline Al-Ajmi, A.M. & (SEPT) & Bhan, V. & (JULY) & Cho, A.R. & (MAY) & Dong, W. & (JULY) \\
\hline Al-Amri, A. & (SEPT) & Bharatha, A. & (MAY) & Cho, J.W. & (MAY) & Dowlatshahi, D. & $(\mathrm{JAN})$ \\
\hline Alcock, S. & $(\mathrm{NOV})$ & Bharwani, L. & $(\mathrm{NOV})$ & Choi, H. & (MAY) & Dubé, M-P. & (MAR) \\
\hline Alfadhel, M. & (JULY) & Black, S.E. & (JULY) & Chouinard, I. & (MAR) & Dubyk, M.D. & (MAR) \\
\hline ALGhasab, N.S. & (NOV) & & $(\mathrm{NOV})$ & Christian, C. & (SEPT) & Dugan, $\mathrm{P}$. & (SEPT) \\
\hline Algird, A. & (MAR) & Blume, W.T. & $(\mathrm{NOV})$ & Christie, S.N. & (MAR) & Dunn, S.E. & (MAR) \\
\hline Alikhani, K. & (MAY) & Board, M. & $(\mathrm{JAN})$ & Chu, H. & (JULY) & Dupré, N. & $(\mathrm{JAN})$ \\
\hline Alkins, R. & (MAY) & Boggild, M. & (MAY) & Chundamala, J. & (NOV) & & (SEPT) \\
\hline Al-Sheeha, M. & (MAY) & Boré, A. & $(\mathrm{NOV})$ & Clarke, G. & $(\mathrm{SEPT})$ & Dysart, K.C. & (MAY) \\
\hline Altay, T. & (NOV) & Bourgeois, P. & (MAR) & Connolly, M.B. & (NOV) & Easaw, J.C. & (JULY) \\
\hline Alturkustani, M. & $(\mathrm{JAN})$ & Bovi, P. & $(\mathrm{JAN})$ & Colom, L.V. & $(\mathrm{JAN})$ & Ebner, F. & (JULY) \\
\hline Anderson, J. & (JULY) & Bovi, T. & $(\mathrm{JAN})$ & Cooper, P.E. & $(\mathrm{SEPT})$ & Elahi, B. & (JULY) \\
\hline Andersen, J. & (JULY) & Bowers, C.A. & $(\mathrm{NOV})$ & & $(\mathrm{SEPT})$ & Elliott, C. & (MAR) \\
\hline Andrade, D. & (NOV) & Boyle, C.A.J. & (MAR) & Cortes, M.D.P. & $(\mathrm{SEPT})$ & Ernemann, U. & (JULY) \\
\hline \multirow[t]{3}{*}{ Ang, L-C. } & $(\mathrm{JAN})$ & Brais, B. & (JAN) & Cortese, L. & (NOV) & Erro M.E. & (JULY) \\
\hline & (MAR) & & $(\mathrm{JAN})$ & Côté, M. & (MAY) & Ersen, A. & (SEPT) \\
\hline & $(\mathrm{NOV})$ & Bray, G.M. & (JULY) & Côté-Mantha, E. & (MAR) & Eskes, G.A. & (SEPT) \\
\hline Appendino, J.P. & (MAY) & & $(\mathrm{NOV})$ & Coté, R. & (NOV) & Eun, M-Y. & (SEPT) \\
\hline Ashraf, G.M. & (MAY) & Brescia Morra,V. & $(\mathrm{JAN})$ & Couldwell, W.T. & (NOV) & Fabian, V. & $(\mathrm{JAN})$ \\
\hline Assaly, M. & (SEPT) & Brigo, F. & $(\mathrm{JAN})$ & Coulter-Mackie, M. & (JULY) & Fallah, A. & $(\mathrm{NOV})$ \\
\hline Atkins, E.J. & (JULY) & Bril, V. & (JULY) & Coutts, S.B. & $(\mathrm{JAN})$ & Fantaneanu, T. & $(\mathrm{JAN})$ \\
\hline Aubé, M. & (MAR) & Brinar, V.V. & $(\mathrm{SEPT})$ & & (MAR) & Fantaneanu, T.A. & $(\mathrm{JAN})$ \\
\hline Aubin-Lemay, C. & $(\mathrm{NOV})$ & Broad, R.W. & (MAR) & Crane, J.D. & (MAR) & Feasby, T. & $(\mathrm{JAN})$ \\
\hline Aurer, I. & $(\mathrm{NOV})$ & Buck, B.H. & $(\mathrm{NOV})$ & Cruz, J.P. & (MAY) & Federico, $\mathrm{P}$. & (MAY) \\
\hline Aviv, R.I. & (MAY) & Bulloch, A.G.M. & (MAR) & Cusimano, M.D. & (JULY) & & (MAY) \\
\hline Azechi, H. & $(\mathrm{JAN})$ & Burke, M.J. & $(\mathrm{NOV})$ & & (NOV) & Fehlings, D. & (JULY) \\
\hline Baek, W. & (MAR) & Burneo, J.G. & (MAY) & da Costa, L. & (SEPT) & Fenchel, M. & (JULY) \\
\hline Bai, H.D. & $(\mathrm{JAN})$ & & $(\mathrm{NOV})$ & Dai, Y. & (JULY) & Fenton, R. & (JULY) \\
\hline Bai, Y. & (SEPT) & & $(\mathrm{NOV})$ & & (NOV) & Fewer, D. & $(\mathrm{NOV})$ \\
\hline Baik, J.S. & (JULY) & Butler, J. & $(\mathrm{NOV})$ & Dale, R.C. & (MAR) & Filla, A. & $(\mathrm{JAN})$ \\
\hline Bal, S. & (JULY) & Cabada T. & (JULY) & Das, $\mathrm{S}$. & (NOV) & Finger, E. & (MAR) \\
\hline Banu, N. & (MAY) & Card, R.T. & (MAR) & Davenport, W.J. & (MAR) & Finsterer, J. & (MAR) \\
\hline Bao, J. & $(\mathrm{NOV})$ & Carlen, P.L. & (MAY) & Davey, P. & (MAY) & Fon, E. & (JULY) \\
\hline Barnett, H.J.M. & $(\mathrm{JAN})$ & Carmant, L. & $(\mathrm{NOV})$ & Dea, N. & (SEPT) & Fong, J.C. & (JULY) \\
\hline Bartlett, E.S. & (MAY) & Casserly, C.S. & (MAY) & DeArmond, S.J. & (MAY) & Fortin, D. & (SEPT) \\
\hline Barun, B. & $(\mathrm{NOV})$ & Castaldo, I. & $(\mathrm{JAN})$ & Debicki, D.B. & (MAY) & & $(\mathrm{NOV})$ \\
\hline Bauman, G. & $(\mathrm{JAN})$ & Castellani, R.J. & $(\mathrm{JAN})$ & & (JULY) & Fournier-Gosselin, M-P. & (SEPT) \\
\hline Beattie, B.L. & (SEPT) & Cattaruzza, T. & (MAY) & Deik, A.F. & (SEPT) & Fox, A.J. & (MAY) \\
\hline Beauchamp, R. & (JULY) & Chae, S.W. & (JULY) & DeJesus-Hernandez, M. & (SEPT) & Fox, S. & (JULY) \\
\hline Beauchemin, $\mathrm{P}$. & $(\mathrm{JAN})$ & Chakraborty, S. & $(\mathrm{JAN})$ & Del Brutto, O.H. & (MAR) & Francoeur, J. & (MAY) \\
\hline \multirow[t]{2}{*}{ Becker, W.J. } & (MAR) & Chalk, C. & $(\mathrm{JAN})$ & & (MAY) & Freedman, M. & (SEPT) \\
\hline & $(\mathrm{NOV})$ & Chan, K.M. & (MAR) & Del Maestro, R. & (SEPT) & Friedman, D. & (SEPT) \\
\hline
\end{tabular}


Author Index to Volume 39 - 2012

\begin{tabular}{|c|c|c|c|c|c|c|c|}
\hline $\mathrm{Fu}, \mathrm{G}-\mathrm{X}$ & (JULY) & Herrmann, N. & $(\mathrm{NOV})$ & Kang, D-W. & (NOV) & Kumar, H. & (JULY) \\
\hline Ganta, K. & (MAY) & Hettinga, B.P. & (MAR) & Kang, S.Y. & (MAY) & & $(\mathrm{NOV})$ \\
\hline Gao, J. & (JULY) & Hill, M.D. & $(\mathrm{JAN})$ & Kapadia, A.N. & (MAY) & Kumar, R. & (MAY) \\
\hline Garcia, P. & (MAY) & & (JULY) & Karamchandani, J. & (NOV) & Kuzniecky, R. & $(\mathrm{NOV})$ \\
\hline \multirow[t]{2}{*}{ Gauthier, S. } & (JULY) & & $(\mathrm{NOV})$ & Karunanayake, C. & (NOV) & Kwon, D.Y. & (JULY) \\
\hline & $(\mathrm{NOV})$ & Hinnell, C. & $(\mathrm{JAN})$ & Kaufmann, A.M. & (NOV) & Kwon, M-J. & (MAR) \\
\hline Gentili, F. & $(\mathrm{NOV})$ & Hobson, D. & (JULY) & Kawamura, A. & (JULY) & Kwon, S-B. & (MAY) \\
\hline Geraghty, M. & (SEPT) & Höftberger, R. & (MAR) & Keats, E.C. & (NOV) & Kwon, S.U. & (NOV) \\
\hline Geschwind, M.D. & (MAY) & Honjo, K. & $(\mathrm{NOV})$ & Keith, J. & $(\mathrm{JAN})$ & Lacny, C. & $(\mathrm{NOV})$ \\
\hline Ghrooda, E. & (NOV) & Hopman, W.M. & (MAR) & Kerchner, G.A. & (JULY) & Lafontaine, A.L. & (JULY) \\
\hline Gillis, B. & (MAY) & Hoque, $\mathrm{T}$. & $(\mathrm{JAN})$ & Kertesz, A. & (MAR) & Laforce, R. Jr. & (JULY) \\
\hline Gillis, C. & (SEPT) & Horger, M. & (JULY) & Ketan, C. & $(\mathrm{JAN})$ & Lam, V. & $(\mathrm{JAN})$ \\
\hline Giordano, I. & $(\mathrm{JAN})$ & Horvath, E. & (SEPT) & Keyzers, M. & (MAY) & La Piana, R. & (SEPT) \\
\hline Girard, G. & (NOV) & & $(\mathrm{NOV})$ & Khan, A. & (NOV) & Larrazabal, R. & (MAR) \\
\hline Girvin J.P. & (NOV) & Houde, J-C. & $(\mathrm{NOV})$ & Khan, F. & (MAY) & Lauzier, F. & (SEPT) \\
\hline Gitlin, J. & (MAY) & Howse, D.C. & $(\mathrm{NOV})$ & Khan, Z.A. & (NOV) & Lavoie, P. & (MAY) \\
\hline Gladstone, D.J. & $(\mathrm{NOV})$ & Hsiung, G-Y.R. & (JULY) & $\mathrm{Ki}, \mathrm{C}-\mathrm{S}$. & (MAR) & Lavorato, D.H. & (MAR) \\
\hline Gladstone, J. & (MAR) & & (SEPT) & & (MAY) & Lee, $C$. & (MAR) \\
\hline Glikstein, R. & (SEPT) & & (SEPT) & Kiefer, G. & (JULY) & Lee, H-G. & $(\mathrm{JAN})$ \\
\hline Goffaux, P. & (SEPT) & $\mathrm{Hu}, \mathrm{X}$. & (MAR) & Kiehl, T.R. & (SEPT) & Lee, H.M. & (SEPT) \\
\hline Goguen, J. & (JULY) & & (JULY) & Kieseier, B.C. & $(\mathrm{JAN})$ & Lee, J.M. & (JULY) \\
\hline Golev, D. & (MAR) & & $(\mathrm{NOV})$ & Kim, E-K. & (NOV) & Lee, K-E. & (MAY) \\
\hline Gordon, J. & (JULY) & $\mathrm{Hu}, \mathrm{Y}$. & (SEPT) & Kim, H-J. & (NOV) & Lee, K-Y. & (MAY) \\
\hline Gordon, M. & (NOV) & Hughes, P.S. & (SEPT) & Kim, H.Y. & (MAR) & Lee, L. & (MAR) \\
\hline \multirow[t]{2}{*}{ Gorter, J.W. } & $(\mathrm{JAN})$ & Huguet, A. & $(\mathrm{JAN})$ & Kim, J. & (MAY) & Lee, P.E. & (SEPT) \\
\hline & (JULY) & Humphreys, P. & (SEPT) & Kim, J.H. & (JULY) & Lee, Y.J. & (MAY) \\
\hline Gotlin, J. & (MAY) & Hunter, G. & (MAR) & Kim, J.S. & (NOV) & Lejeune, J-P. & (MAR) \\
\hline Goyal, M. & (JAN) & Husseini, L. & (JAN) & Kim, K-K. & (JULY) & Lemire, E.G. & (MAY) \\
\hline Griebel, R.W. & (MAY) & Hwang, S.H. & (MAY) & Kim, S.H. & (MAR) & leRoux, A.A. & $(\mathrm{NOV})$ \\
\hline Griesdale, D.E.G. & (SEPT) & Hyson, C. & (MAY) & Kim, Y.S. & (MAR) & Leschyshyn, C. & $(\mathrm{JAN})$ \\
\hline Grimes, D. & (JULY) & Jackson, A.C. & (SEPT) & Kinda, S. & (NOV) & Leung, $\mathrm{M}$. & (SEPT) \\
\hline Grinberg, L.T. & (JULY) & & $(\mathrm{NOV})$ & Kirk, A. & (NOV) & Levert, A. & $(\mathrm{JAN})$ \\
\hline Guan, L-P. & (JAN) & Jacova, C. & (SEPT) & Kirkham, F.J. & (MAR) & Lewis, E.C. & (SEPT) \\
\hline Guberman, A. & $(\mathrm{JAN})$ & Janati, A.B. & $(\mathrm{NOV})$ & Kirpalani, H.M. & (MAY) & $\mathrm{Li}, \mathrm{J}$. & $(\mathrm{JAN})$ \\
\hline Gubitz, G.J. & (SEPT) & Jang, Y.J. & (MAY) & Kirsch, B. & $(\mathrm{JAN})$ & & (JULY) \\
\hline Gui, X. & (JULY) & Javidan, M. & (SEPT) & Kiss, Z.H.T. & (NOV) & Li, S-Q. & $(\mathrm{JAN})$ \\
\hline Guilfoyle, R. & (MAR) & Jeerakathil, T. & (MAR) & Koh, S-B. & (JULY) & $\mathrm{Li}, \mathrm{Y}$. & (JULY) \\
\hline Gunnarson, T. & (MAR) & Jenkins, M.E. & $(\mathrm{NOV})$ & Koh, S-H. & (MAR) & Lian, $\mathrm{K}$. & (MAY) \\
\hline Guo, Z-N. & (MAY) & Jentoft, M.E. & $(\mathrm{NOV})$ & & (MAY) & Lim, Y-M. & (MAY) \\
\hline \multirow[t]{2}{*}{ Habek, M. } & (SEPT) & Jette, N. & (MAY) & Kondziella, D. & (NOV) & & (JULY) \\
\hline & (NOV) & Jia, J. & (JULY) & Korchi, A.M. & $(\mathrm{JAN})$ & Lim-Carter, I. & (JULY) \\
\hline Hachinski, V. & (NOV) & Jog, M.S. & (MAY) & Kovacs, K. & (JULY) & Lin, $\mathrm{T}$. & (MAR) \\
\hline Hahn, C.D. & (MAY) & & (JULY) & & $(\mathrm{SEPT})$ & Lines, M. & (SEPT) \\
\hline Hallock, A. & $(\mathrm{JAN})$ & & (JULY) & & (NOV) & Lipsman, N. & $(\mathrm{JAN})$ \\
\hline Hand, C.K. & (MAR) & & $(\mathrm{NOV})$ & Kramer, A.H. & (MAY) & Liu, C. & (JULY) \\
\hline Harder, S. & (MAY) & Johnson, D.Y. & (MAY) & Krcek, J.P. & $(\mathrm{JAN})$ & Liu, C-Z. & $(\mathrm{JAN})$ \\
\hline Hartung, H-P. & (JAN) & Journeay, W.S. & (SEPT) & & (SEPT) & Liu, H. & (JULY) \\
\hline $\mathrm{He}, \mathrm{Q}$. & (SEPT) & Jung, S. & (MAY) & Kremenchutzky, M. & (MAY) & Liu, S. & (JULY) \\
\hline Heckl, S. & (JULY) & Kadoch, M.A. & (MAY) & Kriegler, S. & (MAY) & Long, Y. & (MAR) \\
\hline Henderson, W.R. & (SEPT) & Kan, P. & (JULY) & Krings, $\mathrm{T}$. & (MAR) & Lownie, S.P. & (MAY) \\
\hline Heran, M.K.S. & (MAY) & Kandiah, N. & (SEPT) & & (JULY) & Lozano, A.M. & $(\mathrm{JAN})$ \\
\hline Hernandez-Ronquillo, L. & $(\mathrm{NOV})$ & Kang, B-H. & (JULY) & & (SEPT) & Lu, E. & (SEPT) \\
\hline
\end{tabular}




\section{Author Index to Volume 39 - 2012}

\begin{tabular}{|c|c|c|c|c|c|c|c|}
\hline Lu, J-Q. & (SEPT) & Miller, B.L. & (MAY) & Pelz, D.M. & (MAY) & Ross, D.C. & (SEPT) \\
\hline \multirow[t]{2}{*}{$\mathrm{Lu}, \mathrm{Z}$. } & (MAR) & & (JULY) & Penagos, L.C. & (SEPT) & Rossi, F. & $(\mathrm{JAN})$ \\
\hline & $(\mathrm{NOV})$ & Miller, E. & (SEPT) & Perry, G. & $(\mathrm{JAN})$ & Rotondo, F. & (SEPT) \\
\hline Lum, C. & (JAN) & Miller, R.J.H. & (JULY) & Perry, J.J. & (SEPT) & Rotstein, D.L. & (MAR) \\
\hline Luo, Y. & $(\mathrm{JAN})$ & Miller, T.S. & (SEPT) & Petersen, R.B. & $(\mathrm{JAN})$ & & (JULY) \\
\hline Macdonald, R.L. & (MAY) & Mirsattari, S.M. & (MAY) & Pettersen, J.A. & (MAY) & Rouleau, G.A. & $(\mathrm{JAN})$ \\
\hline \multirow[t]{2}{*}{ Mackenzie, I.R.A. } & (SEPT) & Mittmann, N. & $(\mathrm{NOV})$ & Pfeffer, G. & (JULY) & & (MAR) \\
\hline & (SEPT) & Miyasaki, J. & (JULY) & Phelix, C.F. & $(\mathrm{JAN})$ & & (MAR) \\
\hline Mackey, A. & (NOV) & Modi, J. & $(\mathrm{JAN})$ & Phielipp, N. & (JULY) & Rousseff, R.T. & (SEPT) \\
\hline Mackie, G. & (JULY) & Moeller, J.J. & (SEPT) & Phillips, S.J. & (SEPT) & Russell, L.J. & (NOV) \\
\hline Maguire, J. & (JULY) & Momjian, S. & $(\mathrm{JAN})$ & & (NOV) & Russo, C.V. & $(\mathrm{JAN})$ \\
\hline Mahmoudi, M. & (JULY) & Montanera, W. & (MAY) & Picard, C. & (MAY) & Rutka, J.T. & (NOV) \\
\hline Mai, F. & (NOV) & Moore, F.G.A. & $(\mathrm{JAN})$ & Pickett, G. & (JULY) & Sadovnick, A.D. & (JULY) \\
\hline Maloney, W. & (JULY) & Moreau, F. & (MAR) & Pillay, N. & (MAY) & Safdar, A. & (MAR) \\
\hline Mandell, D.M. & (SEPT) & Moretto, G. & $(\mathrm{JAN})$ & Pirouzmand, F. & (SEPT) & Salat-Foix, D. & (MAR) \\
\hline Mandzia, J. & $(\mathrm{NOV})$ & Morgan, D.G. & $(\mathrm{NOV})$ & Politzer, N. & (MAY) & Saleh, A. & $(\mathrm{JAN})$ \\
\hline Mansour, M. & (SEPT) & Morhart, M. & (MAR) & Pomero, E. & (SEPT) & Salmon, A. & (MAY) \\
\hline \multirow[t]{2}{*}{ Mansouri, A. } & (SEPT) & Moro, E. & (JULY) & Postuma, R. & (JULY) & Salvatore, E. & $(\mathrm{JAN})$ \\
\hline & $(\mathrm{NOV})$ & Morrow, S.A. & (MAY) & Poulter, M.O. & (SEPT) & Sankar, T. & $(\mathrm{JAN})$ \\
\hline Mao, S. & (JULY) & Muller, P.J. & (JULY) & Power, C. & $(\mathrm{JAN})$ & Savard, M. & $(\mathrm{JAN})$ \\
\hline Marotta, T. & (MAY) & Muro, V.L. & $(\mathrm{NOV})$ & Prasad, A.N. & (JULY) & & (MAR) \\
\hline Martin, A.R. & $(\mathrm{JAN})$ & Murray, B.J. & (MAR) & Prasad, C. & (JULY) & Scheithauer, B.W. & (SEPT) \\
\hline Martin, W. & (JULY)) & Nadeau, J. & $(\mathrm{JAN})$ & Premji, A. & $(\mathrm{JAN})$ & & $(\mathrm{NOV})$ \\
\hline Martínez-Lapiscina, E.H. & (JULY) & Nägele, T. & (JULY) & Pringsheim, T. & (MAR) & Schiffmann, R. & $(\mathrm{JAN})$ \\
\hline Masellis, M. & (JULY) & Naik, N.P. & (MAY) & Pugh, J.A. & (SEPT) & Schoffer, K. & (JULY) \\
\hline Mason, M. & (JULY) & Narayanan, U. & (JULY) & & (SEPT) & Schroeder, G. & $(\mathrm{NOV})$ \\
\hline Massoud, F. & (SEPT) & Nassiri, F. & (JULY) & Putorti, M.L. & $(\mathrm{JAN})$ & Schwartz, M. & (MAY) \\
\hline Mathieu, D. & (SEPT) & Nelson, A.J. & $(\mathrm{JAN})$ & Qiu, W. & (NOV) & & (SEPT) \\
\hline Matouk, C.C. & (MAY) & Noreau, A. & $(\mathrm{JAN})$ & Rabinovici, G.D. & (JULY) & Schweizer, T.A. & (MAY) \\
\hline McCormick, A. & (JULY) & Nunomura, A. & $(\mathrm{JAN})$ & Racine, E. & (MAR) & Seeley, W.W. & (JULY) \\
\hline \multirow[t]{3}{*}{ McDonald, P.J. } & (JULY) & O'Brien, $\mathrm{P}$. & (MAY) & Rademakers, R. & (SEPT) & Sell, E. & (SEPT) \\
\hline & (SEPT) & O'Connor, P.W. & (MAR) & Rahme, R. & (JULY) & Sengdy, P. & (SEPT) \\
\hline & (NOV) & & (SEPT) & Rai, N. & $(\mathrm{JAN})$ & Seo, W-K. & (JULY) \\
\hline McDougall, C.M. & (MAR) & Ogborn, D.I. & (MAR) & Rajput, A. & (JULY) & & (SEPT) \\
\hline McEwan, L. & (MAY) & Oh, K. & (JULY) & Ramsay, D.A. & (MAY) & Seshia, S.S. & $(\mathrm{JAN})$ \\
\hline McKeon, A. & (MAR) & Olson, J.L. & (MAR) & Ranawaya, R. & (MAR) & & (MAR) \\
\hline McLachlan, R.S. & $(\mathrm{NOV})$ & Ortiz, L.D. & (SEPT) & Rasheed, N. & (MAY) & & (MAY) \\
\hline McNamara, P.J. & (MAY) & Oskoui, M. & $(\mathrm{JAN})$ & Receveur, D. & (JULY) & & (MAY) \\
\hline Meddings, J. & (MAR) & & (MAR) & Reidy, Y. & (SEPT) & Seung, S.J. & $(\mathrm{NOV})$ \\
\hline Megyesi, J.F. & $(\mathrm{NOV})$ & Ozretić, D. & $(\mathrm{SEPT})$ & Reifenberger, G. & $(\mathrm{JAN})$ & Shah, L. & $(\mathrm{NOV})$ \\
\hline Mehta, V. & (SEPT) & Palit, G. & (MAY) & Rigby, H. & (JULY) & Shan, X-Y. & (SEPT) \\
\hline Mena, I.X. & (MAR) & Park, B-S. & (MAY) & & (NOV) & Shankar, J.J.S. & (MAR) \\
\hline Mendelson, A.A. & (SEPT) & Park, J. & (MAY) & Rinaldi, C. & $(\mathrm{JAN})$ & & (JULY) \\
\hline \multirow[t]{2}{*}{ Menon, B.K. } & $(\mathrm{JAN})$ & Park, K.W. & (JULY) & Ringer, A.J. & (JULY) & & (JULY) \\
\hline & (JULY) & Parks, N.E. & (SEPT) & Rioux, M-F. & $(\mathrm{JAN})$ & Shanker, V.L. & (SEPT) \\
\hline Mesterman, R. & (JULY) & Parrent, A. & $(\mathrm{NOV})$ & Roberts-South, A. & (NOV) & Sharma, M. & (SEPT) \\
\hline Metz, L.M. & (MAR) & Pascu, O. & $(\mathrm{JAN})$ & Rockwood, K. & (NOV) & & $(\mathrm{NOV})$ \\
\hline Mezei, M.M. & (JULY) & Pasternak, S.H. & (MAY) & Rodriguez, S.L. & (MAR) & Sharp, M.E. & (MAY) \\
\hline Michaud, K. & (MAY) & Patel, V. & $(\mathrm{JAN})$ & Ronco, J.J. & (SEPT) & & (SEPT) \\
\hline Miao, Y. & (JULY) & Paterson, P.G. & (MAR) & Rosa-Neto, P. & (JULY) & Shevell, M.I. & $(\mathrm{JAN})$ \\
\hline \multirow[t]{2}{*}{ Mikulis, D.J. } & (SEPT) & Patten, S.B. & (MAR) & & (NOV) & & (MAR) \\
\hline & & Patterson, C. & $(\mathrm{NOV})$ & Rosner, J. & (NOV) & Shi, G-X. & $(\mathrm{JAN})$ \\
\hline
\end{tabular}




\begin{tabular}{|c|c|c|c|c|c|c|c|}
\hline Shin, H. & (MAY) & Tartaglia, M.C. & (MAY) & Wang, G. & (JULY) & $\mathrm{Xu}, \mathrm{H}$. & (JULY) \\
\hline Shuaib, A. & $(\mathrm{NOV})$ & Tator, C.H. & (MAY) & Wang, $\mathrm{H}$. & (NOV) & $\mathrm{Xu}, \mathrm{W}$. & $(\mathrm{NOV})$ \\
\hline Sieberg, C.B. & $(\mathrm{JAN})$ & & $(\mathrm{NOV})$ & Wang, J. & (JULY) & $\mathrm{Xu}, \mathrm{Y}$. & $(\mathrm{JAN})$ \\
\hline Sirrs, S. & (JULY) & Téllez-Zenteno, J.F. & $(\mathrm{NOV})$ & Wang, L-P. & $(\mathrm{JAN})$ & Yamamoto, T. & $(\mathrm{JAN})$ \\
\hline Smith, K.J. & (MAR) & ten Hove, M.W. & (MAR) & Wang, S-C. & (MAY) & Yan, $\mathrm{H}$. & (JULY) \\
\hline Smith, P.A. & (JULY) & terBrugge, $\mathrm{K}$. & (MAR) & Wang, Y. & (SEPT) & Yang, G. & (MAY) \\
\hline Smyth, H.S. & (JULY) & & (JULY) & Wang, Z. & $(\mathrm{JAN})$ & Yang, H. & (JULY) \\
\hline Snelgrove, B. & (JULY) & Tétreault, M. & $(\mathrm{JAN})$ & Wang, Z. & (MAY) & Yang, Y. & (MAY) \\
\hline Soucy, J.P. & $(\mathrm{NOV})$ & Thai, J.N. & (MAY) & Wasserman, J.K. & $(\mathrm{SEPT})$ & Yang, Z. & (JULY) \\
\hline Spears, J. & (MAY) & Thibodeau, P. & (JAN) & Waters, P.J. & (JULY) & Yip, S. & (MAR) \\
\hline Spence, J.D. & $(\mathrm{NOV})$ & Thiffault, I. & $(\mathrm{JAN})$ & & (JULY) & Yong, V.W. & (SEPT) \\
\hline Steele, M. & $(\mathrm{NOV})$ & Thines, L. & (MAR) & Watt, J. & (JULY) & Youn, J. & (MAY) \\
\hline Stemkowski, P.L. & (JULY) & Thorington, $\mathrm{K}$. & (JULY) & Welten, C.M. & $(\mathrm{NOV})$ & Young, G.B. & $(\mathrm{JAN})$ \\
\hline Stephens, D. & (MAY) & Tomelleri, G. & $(\mathrm{JAN})$ & West, M. & (NOV) & & (MAR) \\
\hline Steven, D.A. & $(\mathrm{NOV})$ & Tommerdahl, M. & $(\mathrm{JAN})$ & Wheelock, W.B. & (NOV) & Yu, H-J. & (MAY) \\
\hline Stiell, I.G. & (SEPT) & Tran, K. & (MAR) & White, J. & $(\mathrm{JAN})$ & Zand, R. & (MAY) \\
\hline Stockler-Ipsiroglu, S. & (JULY) & Tsang, R.Y. & (JULY) & White, J.H. & (MAY) & Žarković, K. & (SEPT) \\
\hline Stoessl, J. & (JULY) & Tucci, T. & $(\mathrm{JAN})$ & White, K.P. & (SEPT) & & $(\mathrm{NOV})$ \\
\hline Strong, M.J. & (MAY) & Tunón T. & (JULY) & Whiting, S. & $(\mathrm{NOV})$ & Zeidman, L.A. & (MAY) \\
\hline Struys, E. & (JULY) & Tupler, R. & (MAR) & Whiting, S.J. & (MAR) & & $(\mathrm{NOV})$ \\
\hline \multirow[t]{2}{*}{ Suchowersky, O. } & (MAR) & Turgeon, A.F. & (SEPT) & Whittingstall, K. & (NOV) & Zeiler, F.A. & $(\mathrm{JAN})$ \\
\hline & (JULY) & Turmel, A. & (MAY) & Williams, J.V.A. & (MAR) & & (JULY) \\
\hline Suh, S.I. & (SEPT) & Uppal, S. & (JULY) & Wilson, B.A. & $(\mathrm{SEPT})$ & & $(\mathrm{SEPT})$ \\
\hline Switzer, L. & (JULY) & Uribe, $\mathrm{H}$. & $(\mathrm{SEPT})$ & Wilson, M.P. & (SEPT) & & $(\mathrm{SEPT})$ \\
\hline Sylvain, M. & $(\mathrm{JAN})$ & & $(\mathrm{NOV})$ & Wirrell, E.C. & (MAR) & & $(\mathrm{NOV})$ \\
\hline Symington, C. & (SEPT) & Vallance, H.D. & (JULY) & & $(\mathrm{NOV})$ & Zhang, A. & $(\mathrm{SEPT})$ \\
\hline \multirow[t]{2}{*}{ Symons, S.P. } & (MAY) & Vanek, I. & (JULY) & Wiwanitkit, V. & (NOV) & Zhang, F. & (SEPT) \\
\hline & (SEPT) & Vargas, M-I. & $(\mathrm{JAN})$ & Wolfson, C. & (MAR) & Zhang, H-L. & (MAY) \\
\hline \multirow[t]{2}{*}{ Syro, L.V. } & (SEPT) & Vellayappan B.A. & $(\mathrm{NOV})$ & Wong, K. & (MAY) & Zheng, P. & (SEPT) \\
\hline & $(\mathrm{NOV})$ & Venderver, A. & $(\mathrm{JAN})$ & Wong-Kisiel, L.C. & (MAR) & Zhong, X. & $(\mathrm{NOV})$ \\
\hline Szeitz, A. & (JULY) & Verhoeff, N.P.L.G. & $(\mathrm{NOV})$ & Wong, V.A. & (JULY) & Zhong, Y. & (JULY) \\
\hline Szuto, A. & $(\mathrm{JAN})$ & Verreault, S. & (SEPT) & Wörner, J. & (JULY) & Zhu, X. & $(\mathrm{JAN})$ \\
\hline Taljaard, M. & (SEPT) & Vinters, H.A. & $(\mathrm{NOV})$ & Worthington, I. & (MAR) & Zlotkin, S.H. & (MAR) \\
\hline Tam, J.H.K. & (MAY) & Vogel, M.N. & (JULY) & Wu, A. & (NOV) & Zochodne, D.W. & (JULY) \\
\hline Tampieri, D. & (SEPT) & von Baeyer, C.L. & $(\mathrm{JAN})$ & Wu, L. & (JULY) & Zuccarello, M. & (JULY) \\
\hline \multirow[t]{2}{*}{ Tang, V. } & $(\mathrm{JAN})$ & Wade, L. & (MAR) & Wu, Y. & $(\mathrm{SEPT})$ & Zygun, D.A. & (MAY) \\
\hline & $(\mathrm{JAN})$ & Walker, R.A. & (JULY) & Wusthoff, C.J. & (MAY) & & \\
\hline Tao, H-M. & (SEPT) & Wallace, $\mathrm{T}$. & (MAR) & Xia, J. & (JULY) & & \\
\hline Tarnopolsky, M.A. & (MAR) & Wang, B.W. & $(\mathrm{SEPT})$ & Xiao, Z. & (JAN) & & \\
\hline
\end{tabular}




\section{Subject Index to Volume 39 - 2012}

\section{5-FLUOROURACIL}

5-Fluorouracil Induced Hyperammonemic

Encephalopathy: Etiopathologic Correlation (JULY)

\section{ABSTRACTS}

Canadian Association of Neuropathologists ABSTRACTS

(JAN)

47th Annual Congress of the CNSF - ABSTRACTS

(MAY)

ACUTE STROKE

Enhancing Acute Ischemic Stroke Interpretation With

Online Aspects Training

(JAN)

Routine CT Angiography in Acute Stroke Does Not

Delay Thrombolytic Therapy

(JULY)

\section{ADEM}

Demyelination After Primary Central Nervous System Lymphoma; Reversed 'Sentinel'

(NOV)

\section{ADENOMA}

Corticotroph Pituitary Stone

(JAN)

\section{ADRENAL SUPPRESSION}

A Possible Link between Fluticasone Propionate and

Tics in Pediatric Asthmatics

(NOV)

aEEG

Amplitude-Integrated Electroencephalography: A

Runaway Horse?

\section{ALPHA SUBHARMONIC}

Slow Alpha Variant: A Report of a 3 for 1 Ratio Subharmonic

ALS

SOD1 Mutations: More to Learn

(MAR)

\section{ALZHEIMER GLIA TYPE II}

5-Fluorouracil Induced Hyperammonemic Encephalopathy: Etiopathologic Correlation (JULY)

\section{ALZHEIMER'S DISEASE}

Untangling the Vascular Web from Alzheimer Disease and Oxidative Stress

Amyloid and Alzheimer's Disease: Inside and Out (MAY)

Multiple Pathologies are Common in Alzheimer Patients in Clinical Trials

(SEPT)

Mixed Dementia in Clinical Trials of Alzheimer's Disease

(SEPT)

Alzheimer's Disease, Cerebrovascular Disease, and the $\beta$-amyloid Cascade

(NOV)

\section{AMANTADINE}

N-Methyl-D-Aspartate Antagonists in Levodopa Induced Dyskinesia: A Meta-Analysis (JULY)
AMIODARONE

A Case of Amiodarone-Associated Myoclonus

Responsive to Levetiracetam

(SEPT)

\section{ANAPLASTIC OLIGODENDROGLIOMA}

Intraventricular Localization of an Anaplastic

Oligodendroglioma: A Rare Event

(SEPT)

\section{ANEURYSM}

Subarachnoid Hemorrhage Following Posterior Spinal Artery Aneurysm Rupture

(JULY)

\section{ANTI-EPILEPTIC DRUG}

Lennox-Gastaut Syndrome: An Update on Treatment

(NOV)

\section{ANTI-HU}

Paraneoplastic Anti-HU Syndrome Associated with

Uterine Tumor

(MAR)

\section{ANTI-JCV ASSAY}

Natalizumab Risk Stratification: Role of a Two-Step Anti-JCV Antibody Assay

(SEPT)

\section{ANTITHROMBOTICS}

Intracranial Non-Occlusive Thrombus and Multiple Strokes in Giant Cell Arteritis

(JAN)

\section{ANTIVIRAL THERAPY}

Delays in Initiation of Acyclovir Therapy in Herpes Simplex Encephalitis

(SEPT)

\section{APHEMIA}

Aphemia after Infarction of the Left Precentral Gyrus and Premotor Area

(SEPT)

\section{AQUAPORIN}

Serum-Positive and -Negative AQP4 Antibody NMO in Chinese Patients

(MAR)

\section{ARTERIOVENOUS MALFORMATIONS}

Spontaneous Occlusion of the Temporal AVM

Associated With Tinnitus

T2-Dark Restricted Diffusion

(MAR)

(SEPT)

\section{ASPECTS}

Enhancing Acute Ischemic Stroke Interpretation with

Online Aspects Training

$(\mathrm{JAN})$

\section{ATYPICAL TERATOID/RHABDOID TUMORS}

Immune Cell Infiltrates in Atypical Teratoid/Rhabdoid Tumors

(SEPT)

\section{AUTOIMMUNE}

Autoantibody Associated Disorders of the CNS in

Children: The List Keeps Growing (MAR)

\section{AUTOIMMUNE EPILEPSY}

Autoimmune Encephalopathies and Epilepsies in

Children and Teenagers

(MAR)

\section{AUTOIMMUNE LIMBIC ENCEPHALITIS}

Refractory Status Epilepticus Associated with Anti-SSA (anti-Ro) Antibodies

(SEPT)

\section{AUTOPHAGY}

Amyloid and Alzheimer's Disease: Inside and Out

(MAY)

\section{AWAKE CRANIOTOMY}

Ethical Challenges with Awake Craniotomy for Tumor

B12

Subacute Combined Degeneration of the Spinal Cord with a Novel Dysosmia

(SEPT)

BELL'S PALSY

Eye Exercises for Treatment of Idiopathic Cranial

Nerve VII Paresis: Pilot Study

BETA AMYLOID

Alzheimer's Disease, Cerebrovascular Disease, and the $\beta$-amyloid Cascade

(NOV)

BOTULINUM TOXIN-A

Botulinum Toxin-A use in Paediatric Hypertonia: Canadian Practice Patterns

(JULY)

BRAIN

Brain Region Specific Monoamine and Oxidative

Changes During Restraint Stress

(MAY)

\section{BRAIN CYSTS}

Multiple Brain Cysts: An Unusual Form of

Radiologically Isolated Syndrome

(SEPT)

\section{BRAIN INJURY}

Concussion Knowledge among Medical Students and Neurology/Neurosurgery Residents

(MAY)

BRAIN ISCHEMIA

T2-Dark Restricted Diffusion

(SEPT)

\section{BRAIN-MACHINE INTERFACES}

Brain-machine Interfaces for Motor Control: A Guide for Neuroscience Clinicians

\section{BRUCELLOSIS}

Brucellosis Manifesting as Chronic Inflammatory

Demyelinating Polyneuropathy

(JULY)

\section{BURDEN OF ILLNESS}

Investigating Ischemic Stroke Costs and Filling a Critical Knowledge Gap 
bvFTD

A 44-Year-Old Man with Profound Behavioural Changes

(JULY)

\section{C9ORF72}

Rapidly Progressive Dementia in a Chinese Patient due to C9ORF72 Mutation

(SEPT)

\section{CALCIFICATION}

Corticotroph Pituitary Stone

(JAN)

\section{CALCIFYING PSEUDONEOPLASM}

Calcifying Pseudoneoplasm of the Neuraxis with Single Nerve Rootlet Involvement

(NOV)

\section{CALCIFYING PSEUDOTUMOR}

Calcifying Pseudoneoplasm of the Neuraxis with Single Nerve Rootlet Involvement

(NOV)

\section{CANADA}

A Canadian Paradox: Tommy Douglas and Eugenics

A Review of Cases of Human Cysticercosis in Canada (MAY)

Neurocysticercosis: A Foreign Parasite Looking for "Permanent Resident" Status? (MAY)

Delays in Carotid Endarterectomy with Symptomatic High-Grade Carotid Stenosis

(SEPT)

\section{CANCER STEM CELLS}

Stem Cells in Brain Tumour Development and Therapy - Two-Sides of the Same Coin

(MAR)

\section{CARBON MONOXIDE POISONING}

Delayed Restricted Diffusion in Carbon Monoxide Leukoencephalopathy

(MAY)

\section{CARDIOVASCULAR RISK FACTOR}

Alzheimer's Disease, Cerebrovascular Disease, and the $\beta$-amyloid Cascade

(NOV)

\section{CAREER CHOICE}

Increasing the Appeal of Neurosurgery to Qualified Medical Students in Canada

(SEPT)

\section{CAROTID FLOW VELOCITY}

Common Carotid Flow Velocity is Associated with Cognition in Older Adults

(JULY)

\section{CAROTID STENOSIS}

NASCET Percent Stenosis Semi-Automated Versus Manual Measurement on CTA (MAY)

Carotid Artery Angioplasty and Stenting for Patients Less than 70 Years-of-Age

(MAY)

\section{CAROTID STENTING}

Carotid Artery Angioplasty and Stenting for Patients Less than 70 Years-of-Age

\section{CASEATING}

Steroid-Dependant Idiopathic Caseating Intracranial Granuloma

(MAR)

\section{CATHETER TWISTING}

Twisted Catheter Causing Baclofen Pump Malfunction: A Case Report

(NOV)

\section{CAVERNOUS SINUS}

Gamma Knife Radiosurgery of Cavernous Sinus Meningiomas: An Institutional Review $\quad$ (NOV)

CD226

CD226 Gly307Ser Association With Neuromyelitis

Optica in Southern Han Chinese

(JULY)

\section{CENTRAL FATIGUE}

Essential Role of Excessive Tryptophan and its Neurometabolites in Fatigue (JAN)

\section{CEREBELLAR SYNDROME}

Epilepsy and Crossed Cerebellar Diaschisis with Persistent Cerebellar Syndrome

\section{CEREBRAL ABSCESS}

Cerebral Abscess Crossing Midline

(MAR)

\section{CEREBRAL FUNCTION MONITORING}

The Impact of Amplitude-Integrated

Electroencephalography on NICU Practice

(MAY)

\section{CEREBRAL INFARCTION}

The Haplotype of the TGF $\beta 1$ Gene Associated with

Cerebral Infarction in Chinese

(SEPT)

\section{CEREBRAL PALSY}

Growing Up with Cerebral Palsy: Contemporary

Challenges of Healthcare Transition (JAN)

Making Links Across the Lifespan in Neurology (JAN)

\section{CEREBRAL VENOUS SINUS THROMBOSIS}

Sex Differences in Adult Cerebral Venous Sinus

Thrombosis: A 10-Year Experience (JAN)

\section{CEREBROFACIAL VENOUS METAMERIC} DISEASE

Cognitive and Mood Profile of Sturge-Weber Syndrome Affecting the Thalamus (MAY)

\section{CEREBROSPINAL FLUID}

Serum-Positive and -Negative AQP4 Antibody NMO in Chinese Patients (MAR)

Cerebrospinal Fluid IL-21 Levels in Neuromyelitis Optica and Multiple Sclerosis

(NOV)

CHARLES MILLER FISHER

Charles Miller Fisher (1913-2012)

\section{CHEMOTHERAPY ASSOCIATED} STEATOHEPATITIS

Chemotherapy-Associated Steatohepatitis with

Temozolomide and Dexamethasone

(JULY)

\section{CHILD}

Spinal CSF Leaks: Mimicker of Primary Headache Disorder in a Child

(MAY)

\section{CHILDREN}

Autoimmune Encephalopathies and Epilepsies in Children and Teenagers

Autoantibody Associated Disorders of the CNS in Children: The List Keeps Growing

(MAR)

\section{CHOLESTEROL}

Cholesterol Lowering, Nutrition and Stroke Prevention

(NOV)

\section{CHRONIC INFLAMMATORY DEMYELINATING} POLYRADICULONEUROPATHY

Brucellosis Manifesting as Chronic Inflammatory Demyelinating Polyneuropathy

(JULY)

\section{CHRONIC PROGRESSIVE EXTERNAL} OPHTHALMOPLEGIA

Levator Palpebrae Biopsy and Diagnosis of Progressive External Ophthalmoplegia

(JULY)

\section{CLINICAL NEUROPATHOLOGICAL} CONFERENCE

Multiple Cerebral Infarcts in Patient with Moyamoya Disease

(MAY)

\section{COGNITION}

Cognitive and Mood Profile of Sturge-Weber Syndrome Affecting the Thalamus

(MAY)

\section{COGNITIVE IMPAIRMENT}

Common Carotid Flow Velocity is Associated with Cognition in Older Adults

\section{COL4A1}

COL4A1 Mutation in a Pediatric Patient Presenting with Post-Ictal Hemiparesis

\section{COMPLICATION}

Conus Medullaris Syndrome as a Complication of Radioisotope Cisternography (MAY) Vasospasm Post Pituitary Surgery: Systematic Review and 3 Case Presentations (NOV)

\section{CONCUSSION}

Concussion Knowledge among Medical Students and Neurology/Neurosurgery Residents (MAY)

Deficiencies in Concussion Education in Canadian Medical Schools (NOV)

Concussion Education: A (Gentle) Knock on the Head for All of Us (NOV) 
Neurocysticercosis: A Foreign Parasite Looking for

"Permanent Resident" Status? (MAY)

Iron - Too Much of a Good Thing (MAY)

Clinical fMRI: A Pre-Surgical Test in Patients with

Medically Intractable Epilepsy (MAY)

Giant Pituitary Tumours: Experience Counts (JULY)

Dyskinesia in Parkinson Disease - An Unmet

Therapeutic Challenge (JULY)

Pyridoxine Dependent Epilepsy: Enduring Mystery and

Continuing Challenges

(JULY)

Neuropathic Pain: Redundant Pathways, Inadequate

Therapy

(JULY)

Mixed Dementia in Clinical Trials of Alzheimer's Disease

(SEPT)

Stroke Genetics and the Chinese Population (SEPT)

Could We Do Better in the Administration of "Justice" to Neurological Patients

(SEPT)

The Use of Natalizumab for Treatment of MS: Do the Risks Outweigh the Gains?

(SEPT)

Surgical Resection and Glioblastoma: Molecular Profiling and Safety

(SEPT)

Technology in Caring for Traumatic Brain Injury: Does What Make Sense Really Do?

(SEPT)

Cholesterol Lowering, Nutrition and Stroke Prevention

Investigating Ischemic Stroke Costs and Filling a

(NOV)

Critical Knowledge Gap

(NOV)

Concussion Education: A (Gentle) Knock on the Head For All of Us

(NOV)

\section{EEG FINDINGS}

Slow Alpha Variant: A Report of a 3 for 1 Ratio Subharmonic

(JAN)

\section{EEG POWER SPECTRUM}

A New Method of Intracranial Pressure Monitoring by EEG Power Spectrum Analysis

(JULY)

\section{ELECTROENCEPHALOGRAPHY}

The Impact of Amplitude-Integrated

Electroencephalography on NICU Practice (MAY)

\section{EMBOLIC STROKE}

Aphemia after Infarction of the Left Precentral Gyrus and Premotor Area

(SEPT)

\section{EMERGENCY MEDICINE}

Patients Referred for TIA May Still Have Persisting Neurological Deficits

\section{ENCEPHALITIS}

Delays in Initiation of Acyclovir Therapy in Herpes Simplex Encephalitis (SEPT)

Could We Do Better in the Administration of "Justice" to Neurological Patients

(SEPT)

ENDOSCOPIC TRANSSPEHNOIDAL SURGERY

Outcomes of Surgically Treated Giant Pituitary Tumours

\section{ENVENOMATION \\ Fatal Cerebellar Hemorrhage Following Australian \\ Brown Snake Envenomation}

(JAN)

\section{EPIDEMIOLOGY}

Health Status, Stress and Life Satisfaction in a

Community Population with MS

(MAR)

\section{EPIDURAL SPINAL ARTERIOVENOUS SHUNTS}

Spinal Epidural Arteriovenous Fistula with Double

Perimedullary Reflux

(MAR)

\section{EPILEPSY}

Immunomodulation in Adult Epilepsy: The Role of

IVIG

(SEPT)

35 Years of Excellence - Epilepsy Program, Western

University

(NOV)

\section{EPILEPSY SURGERY}

Functional MRI Applications in Epilepsy Surgery (MAY)

Clinical fMRI: A Pre-Surgical Test in Patients with

Medically Intractable Epilepsy

(MAY)

\section{ETHICS}

Ethical Challenges with Awake Craniotomy for Tumor

(JAN)

Proven or Unproven? Panel Report on Ethics in the

Translation of Neuroscience

(MAR)

\section{EUGENICS}

A Canadian Paradox: Tommy Douglas and Eugenics

(JAN)

Letter to the Editor - Re: Neuroscience in Nazi Europe Part 1

(MAY)

EXON 3

A Novel Exon 3 Mutation (P66S) in the SOD1 Gene in Familial ALS

(MAR)

\section{EXTENT OF RESECTION}

Does Extent of Resection Impact Survival in Patients Bearing Glioblastoma?

(SEPT)

\section{EYE EXERCISES}

Eye Exercises for Treatment of Idiopathic Cranial

Nerve VII Paresis: Pilot Study

(MAR)

\section{FATIGUE}

Multiple Sclerosis Fatigue is Associated with Reduced Psychomotor Vigilance (MAR)

Fatigue Impact Scale Demonstrates Greater Fatigue in Younger Stroke Survivors

(SEPT)

\section{FATIGUE IMPACT SCALE}

Fatigue Impact Scale Demonstrates Greater Fatigue in Younger Stroke Survivors

(SEPT)

\section{FIBRO-OSSEOUS LESION}

Calcifying Pseudoneoplasm of the Neuraxis with Single Nerve Rootlet Involvement
FIBROUS DYSPLASIA

Pregnancy-Induced Cystic Degeneration of Fibrous Dysplasia

(NOV)

\section{FOURTH VENTRICLE TUMOUR}

Rosette-Forming Glioneuronal Tumour of the 4th Ventricle in a NF1 Patient

(JAN)

FRG1

Effects of Creatine and Exercise on Skeletal Muscle of FRG1-Transgenic Mice

(MAR)

\section{FRONTOTEMPORAL DEMENTIA}

Rapidly Progressive Dementia in a Chinese Patient due to C9ORF72 Mutation

(SEPT)

FRONTOTEMPORAL LOBAR DEGENERATION

Pathologic Evaluation of the Supraoptic and

Paraventricular Nuclei in Dementia

(MAR)

\section{FUNCTIONAL AREAS}

Tractography in the Study of the Human Brain: A Neurosurgical Perspective

(NOV)

\section{FUNCTIONAL MRI}

Functional MRI Applications in Epilepsy Surgery

Clinical fMRI: A Pre-Surgical Test in Patients with

Medically Intractable Epilepsy

(MAY)

FUS

A 44-Year-Old Man with Profound Behavioural Changes

\section{GAMMA KNIFE}

Gamma Knife Radiosurgery of Cavernous Sinus Meningiomas: An Institutional Review (NOV)

\section{GASTROINTESTINAL PERMEABILITY}

Increased Intestinal Permeability and Parkinson Disease Patients: Chicken or Egg?

(MAR)

\section{GELASTIC SEIZURE}

Novel MRI Changes After Gamma Knife for

Hypothalamic Hamartoma in a Child

(JULY)

\section{GENETICS}

Rapidly Progressive Dementia in a Chinese Patient due to C9ORF72 Mutation

(SEPT)

\section{GIANT CELL ARTERITIS}

Intracranial Non-Occlusive Thrombus and Multiple Strokes in Giant Cell Arteritis (JAN)

\section{GIANT PITUITARY ADENOMA}

Outcomes of Surgically Treated Giant Pituitary Tumours

\section{GIANT PITUITARY TUMOURS}

Giant Pituitary Tumours: Experience Counts (JULY) 


\section{CONCUSSION EDUCATION}

Concussion Education: A (Gentle) Knock on the Head for All of Us

(NOV)

CONSENT

Ethical Challenges with Awake Craniotomy for Tumor

(JAN)

\section{CONUS MEDULLARIS SYNDROME}

Conus Medullaris Syndrome as a Complication of Radioisotope Cisternography

(MAY)

\section{CORPUS CALLOSUM}

Partial Agenesis of Corpus Callosum in Sanjad-Sakati Syndrome (p-ACC)

(NOV)

\section{CORTICAL INFARCTION}

Lumbar Radiculopathy - Mimicking Cortical Infarction of the Precentral Region

(MAY)

\section{CORTICOSTEROIDS}

MS Patients Report Excellent Compliance with Oral Prednisone for Acute Relapses

(MAY)

COST

Impact of Disability Status on Ischemic Stroke Costs in Canada in the First Year

(NOV)

\section{CRANIAL NERVE SEVEN PARESIS}

Eye Exercises for Treatment of Idiopathic Cranial

Nerve VII Paresis: Pilot Study

(MAR)

\section{CRANIECTOMY}

Decompressive Craniectomy in Traumatic Brain Injury: The Edge Effect

(SEPT)

\section{C-REACTIVE PROTEIN}

Serum CRP Concentrations and Severity of Ischemic Stroke Subtypes

(JAN)

\section{CREATINE}

Effects of Creatine and Exercise on Skeletal Muscle of FRG1-Transgenic Mice

(MAR)

\section{CREUTZFELDT-JAKOB DISEASE}

Clinical Overlap between Jakob-Creutzfeldt Disease and Lewy Body Disease

(MAY)

\section{CRITICALLY APPRAISED TOPIC}

Temporal Lobe Epilepsy and Hippocampal Stimulation

(NOV)

\section{CROSSED DIASCHISIS}

Epilepsy and Crossed Cerebellar Diaschisis with Persistent Cerebellar Syndrome

\section{CRYPTOCOCCAL INFECTION}

Cryptococcemia in a Patient with Glioblastoma: Case Report and Literature Review

$(\mathrm{NOV})$

\section{CSF LEAK}

Spinal CSF Leaks: Mimicker of Primary Headache

Disorder in a Child

(MAY)

CT

Corticotroph Pituitary Stone

(JAN)

CTA

Routine CT Angiography in Acute Stroke Does Not

Delay Thrombolytic Therapy

(JULY)

\section{CT SCAN}

Technique for Plain CT and CT Angiogram of the Head in an Obese Patient

(JULY)

\section{CUSHING SYNDROME}

Corticotroph Pituitary Stone

(JAN)

\section{CYSTIC DEGENERATION}

Pregnancy-Induced Cystic Degeneration of Fibrous

Dysplasia

(NOV)

\section{CYSTICERCOSIS}

A Review of Cases of Human Cysticercosis in Canada

(MAY)

Neurocysticercosis: A Foreign Parasite Looking for

"Permanent Resident" Status?

(MAY)

Cysticercosis in Canada

(NOV)

CYTOKINE GENE

Cytokine Gene Polymorphisms and Parkinson's

Disease: A Meta-Analysis

(JAN)

\section{DEMENTIA}

Predictors of Cognitive Impairment Severity in Rural Patients at a Memory Clinic (NOV)

4th Canadian Consensus Conference on the Diagnosis and Treatment of Dementia

(NOV)

\section{DERMATOME}

Lumbar Radiculopathy - Mimicking Cortical Infarction of the Precentral Region

(MAY)

\section{DIABETES INSIPIDUS}

Lithium Induced Diabetes Insipidus, Trauma and the

Shrunken Brain

(SEPT)

\section{DIAGNOSIS}

Levator Palpebrae Biopsy and Diagnosis of Progressive

External Ophthalmoplegia

(JULY)

Diagnostic Challenges Revealed From a

Neuropsychiatry Movement Disorders Clinic (NOV) 4th Canadian Consensus Conference on the Diagnosis and Treatment of Dementia

(NOV)

\section{DIET}

Is the Treatment of Multiple Sclerosis Headed in the Wrong Direction?

(MAY)

\section{DIFFUSION RESTRICTION}

Diagnostic Considerations in Acute MS Lesions with Restricted Diffusion on MRI

(JULY)

\section{DIFFUSION WEIGHTED IMAGING}

Clinical Overlap between Jakob-Creutzfeldt Disease and Lewy Body Disease

(MAY)

\section{DIFFUSION-WEIGHTED MR IMAGING}

T2 and DWI in Pilocytic and Pilomyxoid Astrocytoma with Pathologic Correlation

(JULY)

\section{DISTRIBUTED PRACTICE}

Improving the Neurological Exam Skills of Medical

Students

\section{DOOR TO NEEDLE TIMES}

Routine CT Angiography in Acute Stroke Does Not Delay Thrombolytic Therapy

(JULY)

DTI

Tractography in the Study of the Human Brain: A Neurosurgical Perspective (NOV)

DWI

Delayed Restricted Diffusion in Carbon Monoxide

Leukoencephalopathy

(MAY)

DYNAMIC

Dynamic Radiosurgery at the Toronto-Bayview Regional Cancer Centre, 1988-2007 (MAY)

\section{DYSOSMIA}

Subacute Combined Degeneration of the Spinal Cord with a Novel Dysosmia

(SEPT)

\section{DYSPHAGIA}

Isolated Dysphagia after a Small Posterolateral Medullary Infarct: A Case Report

\section{EARLY-ONSET FAMILIAL ALZHEIMER'S DISEASE (EOFAD)}

Early-Onset Familial Alzheimer's Disease (EOFAD)

(JULY)

EARLY RECURRENT ISCHEMIC STROKE

Repeated Systemic Thrombolysis After Early Recurrent Stroke: Always Hazardous?

(JAN)

\section{EDITORIAL}

Kudos to our Reviewers (Along with a Few Suggestions)

Untangling the Vascular Web from Alzheimer Disease and Oxidative Stress

Making Links Across the Lifespan in Neurology

Autoantibody Associated Disorders of the CNS in

Children: The List Keeps Growing (MAR)

SOD1 Mutations: More to Learn (MAR)

Amplitude-Integrated Electroencephalography: A

Runaway Horse?

(MAY) 


\section{GLIOBLASTOMA}

Stem Cells in Brain Tumour Development and Therapy

- Two-Sides of the Same Coin

(MAR)

Does Extent of Resection Impact Survival in Patients

Bearing Glioblastoma?

(SEPT)

Immune Cell Infiltrates in Atypical Teratoid/Rhabdoid Tumors

(SEPT)

Surgical Resection and Glioblastoma: Molecular Profiling and Safety (SEPT)

\section{GLIOBLASTOMA MULTIFORME}

Cerebral Abscess Crossing Midline (MAR)

Cryptococcemia in a Patient with Glioblastoma: Case Report and Literature Review

(NOV)

\section{GLIOMA}

Stem Cells in Brain Tumour Development and Therapy

- Two-Sides of the Same Coin

(MAR)

\section{GRANULOMA}

Steroid-Dependant Idiopathic Caseating Intracranial

Granuloma

(MAR)

\section{GUIDELINES}

Canadian Headache Society Guideline for Migraine Prophylaxis

(MAR)

Canadian Guidelines on Parkinson's Disease (JULY)

Amplitude-Integrated Electroencephalography: A

Runaway Horse?

(MAY)

\section{GYNAECOLOGICAL TUMOR}

Paraneoplastic Anti-HU Syndrome Associated with Uterine Tumor

(MAR)

HALLERVORDEN-SPATZ SYNDROME

A Novel PANK2 Gene Mutation with Sudden-Onset

Dystonia

(MAY)

\section{HAPLOTYPE}

The Haplotype of the TGF $\beta 1$ Gene Associated with

Cerebral Infarction in Chinese

(SEPT)

\section{HEADACHE}

Psychological Interventions for Headache in Children and Adolescents

(JAN)

Canadian Headache Society Guideline for Migraine Prophylaxis

Spinal CSF Leaks: Mimicker of Primary Headache

Disorder in a Child

(MAY)

Occipital Stimulation for Chronic Migraine: Patient

$$
\text { Selection and Complications }
$$

\section{HEALTH SERVICES ACCESSIBILITY}

Delays in Carotid Endarterectomy with Symptomatic

High-Grade Carotid Stenosis

(SEPT)

\section{HEALTH STATUS}

Health Status, Stress and Life Satisfaction in a

Community Population with MS

(MAR)

\section{HEMANGIOBLASTOMA}

Hemangioblastoma Stromal Cells Show Committed Stem Cell Phenotype

(NOV)

\section{HEMORRHAGE}

Fatal Cerebellar Hemorrhage Following Australian

Brown Snake Envenomation

(JAN)

\section{HEPATOTOXICITY}

Chemotherapy-Associated Steatohepatitis with

Temozolomide and Dexamethasone

(JULY)

\section{HEREDITARY SPASTIC PARAPARESIS}

A Novel PLP1 Mutation Further Expands the Clinical

Heterogeneity at the Locus

(MAR)

\section{HEREDITARY SPASTIC PARAPLEGIA}

CYP7B1 Mutations in French-Canadian Hereditary

Spastic Paraplegia Subjects

(JAN)

\section{HERPES SIMPLEX VIRUS}

Delays in Initiation of Acyclovir Therapy in Herpes Simplex Encephalitis (SEPT)

Could We Do Better in the Administration of "Justice" to Neurological Patients

(SEPT)

\section{HIPPOCAMPAL STIMULATION}

Temporal Lobe Epilepsy and Hippocampal Stimulation

(NOV)

\section{HISTORY}

A Canadian Paradox: Tommy Douglas and Eugenics

(JAN)

\section{HISTORY OF MEDICINE}

Wilder Penfield, Man of Letters

(NOV)

\section{HORMONE THERAPY}

Sex Differences in Adult Cerebral Venous Sinus

Thrombosis: A 10-Year Experience

(JAN)

\section{HSO14}

Melanocortin 4 Receptor Mediates Neuropathic Pain Through p38MAPK in Spinal Cord

(JULY)

\section{HUMAN}

Outcomes of Nerve Transfer versus Nerve Graft in Ulnar Nerve Laceration

(MAR)

\section{HUMAN EXPERIMENTATION}

Letter to the Editor - Re: Neuroscience in Nazi Europe Part 1

(MAY)

\section{HUMANITIES}

Wilder Penfield, Man of Letters

(NOV)

\section{HUNTINGTON'S DISEASE}

Predictors of Survival in a Huntington's Disease

$$
\text { Population from Southern Italy }
$$

HYPERAMMONEMIC ENCEPHALOPATHY

5-Fluorouracil Induced Hyperammonemic

Encephalopathy: Etiopathologic Correlation (JULY)

\section{HYPERPERFUSION}

Hyperperfusion Secondary to Middle Cerebral Artery Stenting

(MAY)

\section{HYPERTONIA}

Botulinum Toxin-A use in Paediatric Hypertonia: Canadian Practice Patterns

(JULY)

\section{HYPOMEYLINATION}

TACH Leukodystrophy: Locus Refinement to

Chromosome 10q22.3-23.1

\section{HYPOTHALAMIC HAMARTOMA}

Novel MRI Changes After Gamma Knife for

Hypothalamic Hamartoma in a Child

\section{HYPOTHALAMUS}

Pathologic Evaluation of the Supraoptic and

Paraventricular Nuclei in Dementia

\section{IDIOPATHIC}

Steroid-Dependant Idiopathic Caseating Intracranial

Granuloma

(MAR)

IL-21

Cerebrospinal Fluid IL-21 Levels in Neuromyelitis Optica and Multiple Sclerosis

(NOV)

\section{IMAGING}

Quantitative Volumetric Analysis Post Transsphenoidal Pituitary Adenoma Surgery

(SEPT)

\section{IMMUNE CELLS}

Immune Cell Infiltrates in Atypical Teratoid/Rhabdoid Tumors

(SEPT)

\section{IMMUNOHISTOCHEMISTRY}

Pituicytoma of the Neurohypophysis: Analysis of Cel Proliferation Biomarkers

(NOV)

\section{INBORN ERROR OF METABOLISM}

Variability of Phenotype in Two Sisters with Pyridoxine Dependent Epilepsy

(JULY)

\section{INFECTION}

Cysticercosis in Canada

(NOV)

\section{INFLAMMATION}

Immunomodulation in Adult Epilepsy: The Role of IVIG

(SEPT)

\section{INIENCEPHALY}

Iniencephaly in an Adult Patient

(MAY)

\section{INTRACELLULAR AMYLOID}

Amyloid and Alzheimer's Disease: Inside and Out 


\section{INTRACRANIAL ATHEROSCLEROSIS}

Effect of Statin on Progression of Symptomatic Intracranial Atherosclerosis

(NOV)

\section{INTRACRANIAL NON-OCCLUSIVE THROMBUS \\ Intracranial Non-Occlusive Thrombus and Multiple Strokes in Giant Cell Arteritis}

(JAN)

\section{INTRACRANIAL PRESSURE}

A New Method of Intracranial Pressure Monitoring by EEG Power Spectrum Analysis

(JULY)

\section{INTRACRANIAL PRESSURE MONITOR}

Intracranial Pressure Monitors in Traumatic Brain Injury: A Systematic Review

\section{INTRACRANIAL PRESSURE MONITORING}

Technology in Caring for Traumatic Brain Injury: Does What Make Sense Really Do?

(SEPT)

\section{INTRACRANIAL STENOSIS}

Cholesterol Lowering, Nutrition and Stroke Prevention

(NOV)

\section{INTRACTABLE}

Magnesium as an Effective Adjunct Therapy for Drug Resistant Seizures

(MAY)

\section{INTRATHECAL INFUSION PUMPS}

Twisted Catheter Causing Baclofen Pump Malfunction: A Case Report

(NOV)

\section{IRON DEFICIENCY ANEMIA}

Iron Deficiency Anemia Prevalence at First Stroke or

Transient Ischemic Attack

(MAR)

\section{ISCHEMIA}

Decompressive Craniectomy in Traumatic Brain Injury: The Edge Effect

(SEPT)

\section{ISCHEMIC STROKE}

Serum CRP Concentrations and Severity of Ischemic Stroke Subtypes

Thrombolysis for Acute Ischemic Stroke in a Patient with Moyamoya Disease (SEPT)

Impact of Disability Status on Ischemic Stroke Costs in Canada in the First Year

\section{ISCHEMIC STROKE COST}

Investigating Ischemic Stroke Costs and Filling a

$$
\text { Critical Knowledge Gap }
$$

\section{IVIG}

Immunomodulation in Adult Epilepsy: The Role of IVIG

\section{KNOWLEDGE TRANSFER}

Proven or Unproven? Panel Report on Ethics in the

Translation of Neuroscience

(MAR)

\section{KYNURENIC ACID}

Essential Role of Excessive Tryptophan and its Neurometabolites in Fatigue

(JAN)

\section{LENNOX-GASTAUT SYNDROME}

Lennox-Gastaut Syndrome: An Update on Treatment

(NOV)

\section{LEUKODYSTROPHY}

TACH Leukodystrophy: Locus Refinement to

Chromosome 10q22.3-23.1

\section{LEUKOENCEPHALOPATHY}

Delayed Restricted Diffusion in Carbon Monoxide

Leukoencephalopathy

(MAY)

\section{LEVATOR PALPEBRAE}

Levator Palpebrae Biopsy and Diagnosis of Progressive

External Ophthalmoplegia

(JULY)

\section{LEVETIRACETAM \\ A Case of Amiodarone-Associated Myoclonus \\ Responsive to Levetiracetam}

(SEPT)

\section{LEVODOPA INDUCED DYSKINESIA \\ N-Methyl-D-Aspartate Antagonists in Levodopa \\ Induced Dyskinesia: A Meta-Analysis (JULY) \\ Dyskinesia in Parkinson Disease - An Unmet \\ Therapeutic Challenge \\ (JULY)}

\section{LEWY BODY DISEASE}

Clinical Overlap between Jakob-Creutzfeldt Disease

and Lewy Body Disease

(MAY)

\section{LINEAR SCLERODERMA}

45-Years Between Skin Lesions and CNS Symptoms in a Patient with Scleroderma

(SEPT)

\section{LINKAGE}

TACH Leukodystrophy: Locus Refinement to

Chromosome 10q22.3-23.1

\section{LITHIUM}

Lithium Induced Diabetes Insipidus, Trauma and the Shrunken Brain

\section{LYSOSOME}

Amyloid and Alzheimer's Disease: Inside and Out

\section{MAGNETIC RESONANCE IMAGING}

T2-Dark Restricted Diffusion

Effect of Statin on Progression of Symptomatic

Intracranial Atherosclerosis

\section{MALFORMATION}

Cavernous Malformation of the Optic Chiasm - A

Diagnostic and Treatment Dilemma

(JULY)

\section{MEDICAL EDUCATION}

Improving the Neurological Exam Skills of Medical Students
Treatment Comfort of Adult Neurologists in Childhood Onset Conditions

(MAR)

Concussion Knowledge among Medical Students and Neurology/Neurosurgery Residents (MAY)

Increasing the Appeal of Neurosurgery to Qualified Medical Students in Canada (SEPT)

Deficiencies in Concussion Education in Canadian Medical Schools

(NOV)

\section{MEDICAL SCHOOL}

Deficiencies in Concussion Education in Canadian Medical Schools

\section{MEDULLARY INFRACTION}

Isolated Dysphagia after a Small Posterolateral Medullary Infarct: A Case Report

(MAY)

\section{MEMORY}

Predictors of Cognitive Impairment Severity in Rural

Patients at a Memory Clinic

(NOV)

\section{MENINGEAL MELANOCYTOMA}

Plaque-Type Blue Nevus with Meningeal Melanocytomas

\section{MENINGIOMA}

Transient Radiographic Early Enhancement after Radiotherapy for Meningioma

Gamma Knife Radiosurgery of Cavernous Sinus Meningiomas: An Institutional Review

(NOV)

\section{META-ANALYSIS}

Cytokine Gene Polymorphisms and Parkinson's Disease: A Meta-Analysis

\section{MGMT}

Non-uniform Response to Temozolomide Therapy in a Pituitary Gonadotroph Adenoma

(SEPT)

\section{MIDDLE CEREBRAL ARTERY}

Hyperperfusion Secondary to Middle Cerebral Artery Stenting

(MAY)

\section{MINOR STROKE}

Patients Referred for TIA May Still Have Persisting

$$
\text { Neurological Deficits }
$$

\section{MITOCHONDRIA}

Effects of Creatine and Exercise on Skeletal Muscle of FRG1-Transgenic Mice

(MAR)

\section{MITOCHONDRIAL DISORDER}

Atypical Multiple Lipomatosis as Sole Manifestation of a Mitochondrial Disorder

(MAR)

\section{MIXED DEMENTIA}

Multiple Pathologies are Common in Alzheimer Patients in Clinical Trials (SEPT)

Mixed Dementia in Clinical Trials of Alzheimer's

Disease

(SEPT) 


\section{MONOAMINES}

Brain Region Specific Monoamine and Oxidative Changes During Restraint Stress

(MAY)

\section{MOTOR SYSTEM}

Brain-machine Interfaces for Motor Control: A Guide for Neuroscience Clinicians

(JAN)

\section{MOVEMENT DISORDERS}

Diagnostic Challenges Revealed From a

Neuropsychiatry Movement Disorders Clinic (NOV)

\section{MOYAMOYA DISEASE}

Multiple Cerebral Infarcts in Patient with Moyamoya

Disease

(MAY)

Thrombolysis for Acute Ischemic Stroke in a Patient with Moyamoya Disease

(SEPT)

MRI

Corticotroph Pituitary Stone

Functional MRI Applications in Epilepsy Surgery

Clinical fMRI: A Pre-Surgical Test in Patients with Medically Intractable Epilepsy

(MAY)

Diagnostic Considerations in Acute MS Lesions with Restricted Diffusion on MRI

(JULY)

\section{MULTIPLE SCLEROSIS}

Health Status, Stress and Life Satisfaction in a

Community Population with MS

(MAR)

Multiple Sclerosis Fatigue is Associated with Reduced Psychomotor Vigilance

(MAR)

Is the Treatment of Multiple Sclerosis Headed in the

Wrong Direction?

(MAY)

MS Patients Report Excellent Compliance with Oral

Prednisone for Acute Relapses

(MAY)

Diagnostic Considerations in Acute MS Lesions with Restricted Diffusion on MRI

(JULY)

CD226 Gly307Ser Association With Neuromyelitis

Optica in Southern Han Chinese

(JULY)

The Use of Natalizumab for Treatment of MS: Do the Risks Still Outweigh the Gains? (SEPT)

A New Therapeutic Target for the Treatment of

Multiple Sclerosis

(SEPT)

\section{MUTATION}

Early-Onset Familial Alzheimer's Disease (EOFAD)

(JULY)

MUTATIONS

CYP7B1 Mutations in French-Canadian Hereditary Spastic Paraplegia Subjects

\section{MYASTHENIA GRAVIS}

A Family with Myasthenia Gravis With and Without

Thymoma

(JULY)

\section{MYOCLONUS}

A Case of Amiodarone-Associated Myoclonus Responsive to Levetiracetam

(SEPT)

\section{MYOPATHY}

Atypical Multiple Lipomatosis as Sole Manifestation of a Mitochondrial Disorder

(MAR)

\section{NATALIZUMAB}

Natalizumab Risk Stratification: Role of a Two-Step Anti-JCV Antibody Assay (SEPT) The Use of Natalizumab for Treatment of MS: Do the Risks Outweigh the Gains? (SEPT)

NAZI

Neuroscience in Nazi Europe Part III: Victims of the

Third Reich

(NOV)

NAZI MEDICINE

Letter to the Editor - Re: Neuroscience in Nazi Europe Part 1

(MAY)

\section{NEONATAL SEIZURES}

The Impact of Amplitude-Integrated

Electroencephalography on NICU Practice (MAY)

\section{NEONATES}

Amplitude-Integrated Electroencephalography: A Runaway Horse?

(MAY)

\section{NERVE INJURY}

Outcomes of Nerve Transfer versus Nerve Graft in

Ulnar Nerve Laceration

(MAR

\section{NERVE REPAIR}

Outcomes of Nerve Transfer versus Nerve Graft in

Ulnar Nerve Laceration

(MAR)

\section{NEUROCRITICAL CARE}

Epileptiform Activity in Neurocritical Care Patients

(MAY)

\section{NEUROCYSTICERCOSIS}

A Review of Cases of Human Cysticercosis in Canada

(MAY)

Neurocysticercosis: A Foreign Parasite Looking for

"Permanent Resident" Status?

(MAY)

\section{NEURODEGENERATION OF BRAIN IRON ACCUMULATION DISORDERS}

Iron - Too Much of a Good Thing

(MAY)

\section{NEUROFIBROMATOSIS TYPE 1}

Rosette-Forming Glioneuronal Tumour of the 4th

Ventricle in a NF1 Patient

\section{NEUROHYPOPHYSIS}

Pituicytoma of the Neurohypophysis: Analysis of Cell

Proliferation Biomarkers

(NOV)

\section{NEUROIMAGING}

Iniencephaly in an Adult Patient

(MAY)

\section{NEUROINFLAMMATION}

Sensory Neurons, Ion Channels, Inflammation and the Onset of Neuropathic Pain

(JULY)

\section{NEUROLOGICAL EXAMINATION}

Improving the Neurological Exam Skills of Medical Students

\section{NEUROLOGIST}

John W. Griffin (1942-2011)

\section{NEUROLOGY}

Partial Agenesis of Corpus Callosum in Sanjad-Sakati Syndrome (p-ACC)

(NOV)

\section{NEUROMETABOLIC}

Variability of Phenotype in Two Sisters with Pyridoxine Dependent Epilepsy

(JULY)

\section{NEUROMODULATION}

Occipital Stimulation for Chronic Migraine: Patient

Selection and Complications

(NOV)

\section{NEUROMYELITIS OPTICA}

Serum-Positive and -Negative AQP4 Antibody NMO in Chinese Patients

CD226 Gly307Ser Association With Neuromyelitis

Optica in Southern Han Chinese (JULY)

Cerebrospinal Fluid IL-21 Levels in Neuromyelitis Optica and Multiple Sclerosis

(NOV)

\section{NEUROPATHIC PAIN}

Melanocortin 4 Receptor Mediates Neuropathic Pain Through p38MAPK in Spinal Cord (JULY)

Neuropathic Pain: Redundant Pathways, Inadequate Therapy

\section{NEUROPATHOLOGY}

Canadian Association of Neuropathologists ABSTRACTS

(JAN)

\section{NEUROPROSTHETICS}

Brain-machine Interfaces for Motor Control: A Guide for Neuroscience Clinicians

\section{NEURORADIOLOGY}

Intraventricular Localization of an Anaplastic

Oligodendroglioma: A Rare Event

(SEPT)

\section{NEUROSCIENCE}

Neuroscience in Nazi Europe Part III: Victims of the Third Reich

(NOV)

\section{NEUROSURGEONS}

Is this Subarachnoid Hemorrhage Significant? A

National Survey of Neurosurgeons

(SEPT)

\section{NEUROSURGERY}

Increasing the Appeal of Neurosurgery to Qualified

Medical Students in Canada

(SEPT)

Remembering Tom Morley (1920 - 2012) 


\section{NOCARDIA}

Cerebral Abscess Crossing Midline

(MAR)

NUTRITION

Cholesterol Lowering, Nutrition and Stroke Prevention

(NOV)

OBESE

Technique for Plain CT and CT Angiogram of the Head in an Obese Patient

(JULY)

\section{OBITUARY}

Dr. John W. Griffin (1942-2011)

Bill McCormick (1942-2011)

Charles Miller Fisher (1913-2012)

Remembering Tom Morley (1920-2012)

Donald W. Baxter (1926-2012)

\section{OPTIC CHIASM}

Cavernous Malformation of the Optic Chiasm - A

Diagnostic and Treatment Dilemma

(JULY)

\section{OUTCOME}

Surgery for Unruptured Intracranial Aneurysms in the ISAT and ISUIA Era

(MAR)

\section{OXIDATIVE STRESS}

Biomarkers of Oxidative Stress in Vascular Dementia Patients

(JAN)

Untangling the Vascular Web from Alzheimer Disease and Oxidative Stress

Brain Region Specific Monoamine and Oxidative Changes During Restraint Stress

\section{OXYTOCIN}

Pathologic Evaluation of the Supraoptic and Paraventricular Nuclei in Dementia

\section{p38MAPK \\ Melanocortin 4 Receptor Mediates Neuropathic Pain Through p38MAPK in Spinal Cord}

(JULY)

\section{P66S}

A Novel Exon 3 Mutation (P66S) in the SOD1 Gene in Familial ALS

(MAR)

\section{PAEDIATRICS}

Botulinum Toxin-A use in Paediatric Hypertonia:

$$
\text { Canadian Practice Patterns }
$$

PAIN

Occipital Stimulation for Chronic Migraine: Patient

Selection and Complications

(NOV)

\section{PANK2}

A Novel PANK2 Gene Mutation with Sudden-Onset Dystonia

(MAY)

\section{PANTOTHENATE KINASE-ASSOCIATED NEURODEGENERATION}

A Novel PANK2 Gene Mutation with Sudden-Onset Dystonia
Iron - Too Much of a Good Thing

(MAY)

PARANEOPLASTIC

Paraneoplastic Anti-HU Syndrome Associated with

Uterine Tumor

(MAR)

\section{PARKINSON'S DISEASE}

Cytokine Gene Polymorphisms and Parkinson's

Disease: A Meta-Analysis

(JAN)

Increased Intestinal Permeability and Parkinson Disease Patients: Chicken or Egg? (MAR)

Canadian Guidelines on Parkinson's Disease (JULY)

N-Methyl-D-Aspartate Antagonists in Levodopa

Induced Dyskinesia: A Meta-Analysis (JULY)

Postural Instability and Cognitive Dysfunction in Early

Parkinson's Disease

(JULY)

Dyskinesia in Parkinson Disease - An Unmet

Therapeutic Challenge

(JULY)

\section{PARRY-ROMBERG}

45-Years Between Skin Lesions and CNS Symptoms in

a Patient with Scleroderma

(SEPT)

\section{PATCH CLAMP}

Sensory Neurons, Ion Channels, Inflammation and the

Onset of Neuropathic Pain

(JULY)

\section{PATHOLOGY}

Multiple Pathologies are Common in Alzheimer

Patients in Clinical Trials

(SEPT)

\section{PCNSL}

Demyelination After Primary Central Nervous System Lymphoma; Reversed 'Sentinel'

(NOV)

\section{PEDIATRIC}

Psychological Interventions for Headache in Children and Adolescents

(JAN)

\section{PEDIATRIC NEUROLOGY}

Pediatric Neurology Training in Canada: Current Status and Future Directions

(MAY)

\section{PELIZAEUS MERZBACHER DISEASE}

A Novel PLP1 Mutation Further Expands the Clinical

Heterogeneity at the Locus

(MAR)

\section{PENFIELD}

Wilder Penfield, Man of Letters

$(\mathrm{NOV})$

\section{PERIMEDULLARY VENOUS REFLUX}

Spinal Epidural Arteriovenous Fistula with Double

Perimedullary Reflux

(MAR)

PERIODIC EPILEPTIFORM DISCHARGES

Epileptiform Activity in Neurocritical Care Patients

(MAY)

\section{PERIPHERAL NEUROPATHY}

Sensory Neurons, Ion Channels, Inflammation and the

Onset of Neuropathic Pain

\section{PHENOTYPE}

Early-Onset Familial Alzheimer's Disease (EOFAD)

(JULY)

\section{PHOSPHO-NR2B}

The Effects of Exercise Intensity on p-NR2B

Expression in Cerebral Ischemic Rats

(SEPT)

\section{PHYSICAN SURVEY}

Treatment Comfort of Adult Neurologists in Childhood Onset Conditions

(MAR)

\section{PILOCYTIC ASTROCYTOMA}

T2 and DWI in Pilocytic and Pilomyxoid Astrocytoma with Pathologic Correlation

(JULY)

\section{PILOMYXOID ASTROCYTOMA}

T2 and DWI in Pilocytic and Pilomyxoid Astrocytoma with Pathologic Correlation

(JULY)

\section{PIRIFORMIS SYNDROME}

The Diagnosis and Management of Piriformis Syndrome: Myths and Facts

(SEPT)

\section{PITUICYTOMA}

Pituicytoma of the Neurohypophysis: Analysis of Cell Proliferation Biomarkers (NOV)

\section{PITUITARY ADENOMA}

Non-uniform Response to Temozolomide Therapy in a Pituitary Gonadotroph Adenoma (SEPT)

Vasospasm Post Pituitary Surgery: Systematic Review and 3 Case Presentations

(NOV)

\section{PITUITARY ADENOMA SURGERY}

Quantitative Volumetric Analysis Post Transsphenoidal Pituitary Adenoma Surgery

(SEPT)

PITUITARY GLAND

Corticotroph Pituitary Stone

\section{PLAQUE-TYPE BLUE NEVUS}

Plaque-Type Blue Nevus with Meningeal Melanocytomas

\section{POSTERIOR SPINAL ARTERY}

Subarachnoid Hemorrhage Following Posterior Spinal Artery Aneurysm Rupture

(JULY)

POSTOPERATIVE COMPLICATIONS

Twisted Catheter Causing Baclofen Pump Malfunction: A Case Report (NOV)

\section{POSTURAL INSTABILITY}

Postural Instability and Cognitive Dysfunction in Early Parkinson's Disease (JULY)

\section{PREGNANCY}

Pregnancy-Induced Cystic Degeneration of Fibrous

Dysplasia

(NOV) 


\section{PRESSURE INDEX}

A New Method of Intracranial Pressure Monitoring by EEG Power Spectrum Analysis

(JULY)

\section{PRIMARY CENTRAL NERVOUS SYSTEM LYMPHOMA \\ Inflammatory Demyelinating Brain Lesions Heralding Primary CNS Lymphoma (JAN)}

\section{PRIMARY INTRAOCULAR LYMPHOMA}

Inflammatory Demyelinating Brain Lesions Heralding Primary CNS Lymphoma

(JAN)

\section{PROGNOSIS}

Quantitative Volumetric Analysis Post Transsphenoidal Pituitary Adenoma Surgery

(SEPT)

\section{PROTEOLIPID PROTEIN}

A Novel PLP1 Mutation Further Expands the Clinical Heterogeneity at the Locus

(MAR)

\section{PSEUDOPROGRESSION}

Transient Radiographic Early Enhancement after Radiotherapy for Meningioma (JAN)

\section{PSYCHIATRY}

Diagnostic Challenges Revealed From a Neuropsychiatry Movement Disorders Clinic (NOV)

\section{PSYCHOLOGICAL}

Psychological Interventions for Headache in Children and Adolescents

(JAN)

\section{PYRIDOXINE DEPENDENT EPILEPSY}

Pyridoxine Dependent Epilepsy: Enduring Mystery and Continuing Challenges

(JULY)

\section{RADIATION}

Transient Radiographic Early Enhancement after Radiotherapy for Meningioma

\section{RADICULOPATHY}

Lumbar Radiculopathy - Mimicking Cortical Infarction of the Precentral Region

(MAY)

\section{RADIOISOTOPE CISTERNOGRAPHY}

Conus Medullaris Syndrome as a Complication of Radioisotope Cisternography

\section{RADIOLOGICALLY ISOLATED SYNDROME}

Multiple Brain Cysts: An Unusual Form of Radiologically Isolated Syndrome

\section{RADIOSURGERY}

Dynamic Radiosurgery at the Toronto-Bayview Regional Cancer Centre, 1988-2007 (MAY)

Novel MRI Changes After Gamma Knife for Hypothalamic Hamartoma in a Child (JULY)

\section{REFRACTORY}

Magnesium as an Effective Adjunct Therapy for Drug Resistant Seizures

(MAY)

\section{REFRACTORY STATUS}

Status Epilepticus: A Review, With Emphasis on Refractory Cases

(MAR)

\section{RELAPSES}

MS Patients Report Excellent Compliance with Oral

Prednisone for Acute Relapses

(MAY)

\section{REPERFUSION}

Intra-arterial Verapamil-Induced Seizures: Drug

Toxicity or Rapid Reperfusion?

(JULY)

\section{RESIDENCY TRAINING}

Pediatric Neurology Training in Canada: Current Status and Future Directions

(MAY)

\section{RESOLUTION}

Spontaneous Occlusion of the Temporal AVM

Associated With Tinnitus

(MAR)

\section{RESPIRATORY CHAIN}

Atypical Multiple Lipomatosis as Sole Manifestation of a Mitochondrial Disorder

(MAR)

\section{REVIEWERS}

Kudos to our Reviewers (Along with a Few Suggestions)

\section{RISK STRATIFICATION}

Natalizumab Risk Stratification: Role of a Two-Step

Anti-JCV Antibody Assay

(SEPT)

\section{ROSETTE-FORMING GLIONEURONAI TUMOUR}

Rosette-Forming Glioneuronal Tumour of the 4th

Ventricle in a NF1 Patient

\section{RUFINAMIDE}

Lennox-Gastaut Syndrome: An Update on Treatment

(NOV)

\section{RURAL}

Predictors of Cognitive Impairment Severity in Rural Patients at a Memory Clinic

(NOV)

\section{SANJAD-SAKATI SYNDROME}

Partial Agenesis of Corpus Callosum in Sanjad-Sakati Syndrome (p-ACC)

(NOV)

\section{SCIATICA}

The Diagnosis and Management of Piriformis Syndrome: Myths and Facts

(SEPT)

\section{SEIZURES}

Magnesium as an Effective Adjunct Therapy for Drug Resistant Seizures
Epileptiform Activity in Neurocritical Care Patients

Intra-arterial Verapamil-Induced Seizures: Drug Toxicity or Rapid Reperfusion? (JULY)

COL4A1 Mutation in a Pediatric Patient Presenting with Post-Ictal Hemiparesis (SEPT)

45-Years Between Skin Lesions and CNS Symptoms in a Patient with Scleroderma (SEPT)

\section{SEMI-AUTOMATED}

NASCET Percent Stenosis Semi-Automated Versus Manual Measurement on CTA (MAY)

\section{SENSORY NEURON}

Neuropathic Pain: Redundant Pathways, Inadequate Therapy

(JULY)

\section{SENTINEL}

Demyelination After Primary Central Nervous System Lymphoma; Reversed 'Sentinel'

(NOV)

SEX

Sex Differences in Adult Cerebral Venous Sinus Thrombosis: A 10-Year Experience

\section{SJOGREN'S SYNDROME}

Refractory Status Epilepticus Associated with Anti-SSA (anti-Ro) Antibodies

(SEPT)

\section{SLOW ALPHA VARIANT}

Slow Alpha Variant: A Report of a 3 for 1 Ratio Subharmonic

\section{SNAKEBITE}

Fatal Cerebellar Hemorrhage Following Australian Brown Snake Envenomation

SOD1

A Novel Exon 3 Mutation (P66S) in the SOD1 Gene in Familial ALS

SOD1 Mutations: More to Learn (MAR)

\section{SOMATOSENSORY}

Dopamine Alters Tactile Perception in Parkinson's Disease

\section{SPEECH DISORDERS}

Aphemia after Infarction of the Left Precentral Gyrus and Premotor Area

(SEPT)

SPG5A

CYP7B1 Mutations in French-Canadian Hereditary Spastic Paraplegia Subjects

\section{SPINAL CORD}

Spinal Epidural Arteriovenous Fistula with Double Perimedullary Reflux

(MAR)

\section{STATINS}

Effect of Statin on Progression of Symptomatic Intracranial Atherosclerosis 


\section{STATUS EPILEPTICUS}

Epilepsy and Crossed Cerebellar Diaschisis with Persistent Cerebellar Syndrome (JAN)

Status Epilepticus: A Review, With Emphasis on Refractory Cases

Refractory Status Epilepticus Associated with Anti-SSA (anti-Ro) Antibodies

(SEPT)

\section{STEM CELLS}

Hemangioblastoma Stromal Cells Show Committed Stem Cell Phenotype

(NOV)

\section{STENTING}

Hyperperfusion Secondary to Middle Cerebral Artery Stenting

(MAY)

STONE

Corticotroph Pituitary Stone (JAN)

\section{STROKE}

Iron Deficiency Anemia Prevalence at First Stroke or Transient Ischemic Attack

(MAR)

Multiple Cerebral Infarcts in Patient with Moyamoya Disease

(MAY)

Isolated Dysphagia after a Small Posterolateral Medullary Infarct: A Case Report (MAY)

Carotid Artery Angioplasty and Stenting for Patients Less than 70 Years-of-Age

(MAY)

Fatigue Impact Scale Demonstrates Greater Fatigue in Younger Stroke Survivors (SEPT)

Delays in Carotid Endarterectomy with Symptomatic High-Grade Carotid Stenosis (SEPT) Stroke Genetics and the Chinese Population (SEPT) Improvement in Thrombolytic Therapy Administration in Acute Stroke with Feedback

(NOV)

\section{STROKE CLASSIFICATION}

Serum CRP Concentrations and Severity of Ischemic Stroke Subtypes

\section{STROKE GENETICS}

Stroke Genetics and the Chinese Population

\section{STROKE NEUROLOGY}

Bill McCormick (1942 - 2011)

(JAN)

\section{STUDENTS}

Increasing the Appeal of Neurosurgery to Qualified

$$
\text { Medical Students in Canada }
$$

\section{STURGE-WEBER SYNDROME}

Cognitive and Mood Profile of Sturge-Weber Syndrome Affecting the Thalamus

(MAY)

\section{SUBACUTE DEGENERATION}

Subacute Combined Degeneration of the Spinal Cord with a Novel Dysosmia

(SEPT)

\section{SUBARACHNOID HEMORRHAGE}

Subarachnoid Hemorrhage Following Posterior Spinal Artery Aneurysm Rupture

(JULY)
Is this Subarachnoid Hemorrhage Significant? A

National Survey of Neurosurgeons

(SEPT)

\section{SUBDURAL}

Lithium Induced Diabetes Insipidus, Trauma and the Shrunken Brain

(SEPT)

\section{SUPPLEMENT}

Canadian Association of Neuropathologists ABSTRACTS

15TH Biennial Canadian Neuro-Oncology Meeting PROGRAM and ABSTRACTS (JAN)

Canadian Headache Society Guideline for Migraine Prophylaxis (MAR)

47th Annual Congress of the CNSF - ABSTRACTS

(MAY)

Canadian Guidelines on Parkinson's Disease (JULY)

4th Canadian Consensus Conference on the Diagnosis and Treatment of Dementia

(NOV)

35 Years of Excellence - Epilepsy Program, Western

University

(NOV)

\section{SURGERY}

Does Extent of Resection Impact Survival in Patients

$$
\text { Bearing Glioblastoma? }
$$

\section{SURGICAL RESECTION}

Surgical Resection and Glioblastoma: Molecular

Profiling and Safety

(SEPT)

\section{SURGICAL TREATMENT}

Surgery for Unruptured Intracranial Aneurysms in the ISAT and ISUIA Era

(MAR)

\section{SURVEY}

Is this Subarachnoid Hemorrhage Significant? A National Survey of Neurosurgeons

(SEPT)

\section{SURVIVAL ANALYSIS}

Predictors of Survival in a Huntington's Disease

Population from Southern Italy

(JAN)

\section{SYSTEMATIC REVIEW}

Intracranial Pressure Monitors in Traumatic Brain

Injury: A Systematic Review

(SEPT)

\section{SYSTEMIC THROMBOLYSIS}

Repeated Systemic Thrombolysis After Early Recurrent Stroke: Always Hazardous?

\section{TACTILE PERCEPTION}

Dopamine Alters Tactile Perception in Parkinson's

Disease

\section{TEMOZOLOMIDE}

Chemotherapy-Associated Steatohepatitis with Temozolomide and Dexamethasone

Non-uniform Response to Temozolomide Therapy in a Pituitary Gonadotroph Adenoma
Cryptococcemia in a Patient with Glioblastoma: Case Report and Literature Review

(NOV)

\section{TEMPORAL LOBE EPILEPSY}

Temporal Lobe Epilepsy and Hippocampal Stimulation (NOV)

\section{THOMAS PATERSON MORLEY}

Remembering Tom Morley (1920 - 2012)

(NOV)

\section{THROMBOLYSIS}

Thrombolysis for Acute Ischemic Stroke in a Patient with Moyamoya Disease (SEPT)

Improvement in Thrombolytic Therapy Administration in Acute Stroke with Feedback

(NOV)

\section{THYMOMA}

A Family with Myasthenia Gravis With and Without Thymoma

(JULY)

TIA

Patients Referred for TIA May Still Have Persisting Neurological Deficits

\section{TICS}

A Possible Link between Fluticasone Propionate and Tics in Pediatric Asthmatics

(NOV)

\section{TINNITUS}

Spontaneous Occlusion of the Temporal AVM Associated With Tinnitus

(MAR)

\section{TODD'S PARALYSIS}

COL4A1 Mutation in a Pediatric Patient Presenting with Post-Ictal Hemiparesis

(SEPT)

\section{TOURETTE'S SYNDROME}

A Possible Link between Fluticasone Propionate and Tics in Pediatric Asthmatics

\section{TRACTOGRAPHY}

Tractography in the Study of the Human Brain: A Neurosurgical Perspective (NOV)

\section{TRAINING}

Enhancing Acute Ischemic Stroke Interpretation with Online Aspects Training

(JAN)

\section{TRAINING INTENSITY}

The Effects of Exercise Intensity on p-NR2B

Expression in Cerebral Ischemic Rats

\section{TRANSFORMING GROWTH FACTOR BETA 1}

The Haplotype of the TGF $\beta 1$ Gene Associated with Cerebral Infarction in Chinese (SEPT)

\section{TRANSIENT ISCHEMIC ATTACK}

Iron Deficiency Anemia Prevalence at First Stroke or Transient Ischemic Attack

(MAR) 


\section{TRANSITION}

Growing Up with Cerebral Palsy: Contemporary

Challenges of Healthcare Transition

Making Links Across the Lifespan in Neurology (JAN)

Treatment Comfort of Adult Neurologists in Childhood Onset Conditions

(MAR)

\section{TRANSLATION}

Proven or Unproven? Panel Report on Ethics in the

Translation of Neuroscience

(MAR)

TRANSLATIONAL NEUROSCIENCE

A New Therapeutic Target for the Treatment of Multiple Sclerosis

TRAUMA

Decompressive Craniectomy in Traumatic Brain Injury: The Edge Effect

(SEPT)

\section{TRAUMATIC BRAIN INJURY}

Intracranial Pressure Monitors in Traumatic Brain Injury: A Systematic Review

Technology in Caring for Traumatic Brain Injury: Does What Make Sense Really Do?

\section{TREATMENT}

The Diagnosis and Management of Piriformis Syndrome: Myths and Facts (SEPT) 4th Canadian Consensus Conference on the Diagnosis and Treatment of Dementia

(NOV)

\section{TRYPTOPHAN}

Essential Role of Excessive Tryptophan and its Neurometabolites in Fatigue (JAN)

\section{TUMORS}

Intraventricular Localization of an Anaplastic

Oligodendroglioma: A Rare Event

(SEPT)

\section{UNRUPTURED INTRACRANIAL ANEURYSMS}

Surgery for Unruptured Intracranial Aneurysms in the ISAT and ISUIA Era

(MAR)

\section{VASCULAR DEMENTIA}

Biomarkers of Oxidative Stress in Vascular Dementia

Patients

(JAN)

\section{VASCULITIS}

Multiple Cerebral Infarcts in Patient with Moyamoya

Disease

(MAY)

\section{VASCULOGENESIS}

Hemangioblastoma Stromal Cells Show Committed Stem Cell Phenotype

(NOV)

\section{VASOSPASM}

Vasospasm Post Pituitary Surgery: Systematic Review and 3 Case Presentations

(NOV)

\section{VERAPAMIL}

Intra-arterial Verapamil-Induced Seizures: Drug Toxicity or Rapid Reperfusion?

\section{VESSEL ANALYSIS}

NASCET Percent Stenosis Semi-Automated Versus

Manual Measurement on CTA

(MAY)

\section{VICTIMS}

Neuroscience in Nazi Europe Part III: Victims of the Third Reich

(NOV)

\section{VITAMIN B6}

Variability of Phenotype in Two Sisters with Pyridoxine Dependent Epilepsy

(JULY) 